\title{
PENENTUAN ZONA PRIORITAS PENGELOLAAN AIR LIMBAH DOMESTIK DENGAN METODE SKORING PEMBOBOTAN DI KECAMATAN MAMASA
}

\author{
Widi Astuti ${ }^{1 *}$ dan Yustika Kusumawardani ${ }^{2}$ \\ ${ }^{1,2}$ Program Studi D3 Teknik Lingkungan Universitas Pandanaran \\ Jalan Banjarsari Barat No 1 Pedalangan, Banyumanik Semarang \\ Email*: widi_unp@yahoo.com
}

\begin{abstract}
ABSTRAK
Pengelolaan air limbah domestik di Kabupaten Mamasa saat ini belum menjadi perhatian masyarakat maupun pemerintah. Akibat dari belum adanya sistem IPAL maupun SPAL menyebabkan masyarakat membuang limbah masih tergabung dengan drainase dan sungai. Sistem sanitasi komunal menjadi salah satu alternatif pada lokasi-lokasi yang memiliki kepadatan penduduk yang tinggi atau pada kawasan kumuh. Penelitian ini memberikan gambaran tentangcara menentukan wilayah prioritas pembangunan sistem pengelolaan air limbah domestik di Kecamatan Mamasa. Penelitian ini dianalisis melalui Penentuan Zona Perencanaan dan Zona Prioritas melalui metode scoring atau pembobotan berdasarkan kriteria tertentu. Hasil analisis penilaian rata-rata skor penentuan zona perencanaan, Desa/Kelurahan Mamasa dan Osango memerlukan SPAL terpusat skala kawasan. Hasil perhitungan skoring Penentuan Wilayah Prioritas Kelurahan Mamasa masuk dalam zona B skor 270, dengan skor tertinggi sehingga menjadi usulan prioritas lokasi pembangunan SPAL skala kawasan.
\end{abstract}

Kata kunci : Pengelolaan Air Limbah, Metode Skoring, Kecamatan Mamasa

\section{PENDAHULUAN}

Sanitasi merupakan salah satu pelayanan dasar yang kurang mendapatkan perhatian dan bukan merupakan prioritas pembangunan di daerah. Kondisi sanitasi yang buruk dapat berpengaruh terhadap menurunnya kualitas lingkungan hidup dan kesehatan masyarakat. Penyelenggaraan pengelolaan air limbah domestik bertujuan untuk meningkatkan akses pelayanan air limbah domestik yang ramah lingkungan, sehingga tercapai peningkatan kualitas kehidupan masyarakat dan lingkunganyang lebih baik dan sehat (Damanhuri,2010). Undang-undang Nomor 23 Tahun 2014 tentang Pemerintahan Daerah, menyatakan bahwa pengelolaan air limbah termasuk dalam urusan wajib Pemerintah Daerah dan merupakan pelayanan dasar bagi masyarakat.

Kabupaten Mamasa merupakan kabupaten pemekaran dari Kabupaten Polewali Mamasa dengan laju pertumbuhan penduduk per tahun sebesar 2,32 persen. Kepadatan penduduk rata-rata di Kabupaten Mamasa tahun 2014 adalah 50 jiwa/ $\mathrm{km}^{2}$.Pengelolaan air limbah domestik di Kabupaten Mamasa saat ini belum menjadi perhatian masyarakat maupun pemerintah. Pengelolaan air limbah domestik yang berasal dari WC (black water) pada umumnya masih bersifat konvensional menggunakan sistem pengolahan yang bersifat individual maupun komunal yaitu menggunakan septic tank. Selain itu kegiatankegiatan yang dilakukan masyarakat Kabupaten Mamasa dalam membuang air limbahnya, antara lain masih ke saluran air dekat rumah masingmasing, membuang air limbah langsung ke sungai atau menampung air limbah rumah tangga ke dalam lubang yang dibuat dekat kamar mandi.

Dalam rangka mengantisipasi pertumbuhan penduduk di kawasan perkotaan di Kecamatan Mamasa, maka diperlukan sarana sanitasi yang memadai khususnya berkaitan dengan limbah domestik. Akibat dari belum adanya sistem IPAL maupun SPAL menyebabkan masyarakat membuang limbah masih tergabung dengan drainase dan sungai. Sistem sanitasi komunal 
menjadi salah satu alternatif pada lokasi-lokasi yang memiliki kepadatan penduduk yang tinggi atau pada kawasan kumuh (Nurhidayat, 2009). Namun kendala yang ditemui di Kabupaten Mamasa adalah terbatasnya lahan untuk pembangunan sistem sanitasi komunal serta masih rendahnya kesadaran masyarakat dalam hal stop BABS. Pemerintah Kabupaten Mamasa saat ini belum memiliki Instalasi Pengolahan Air Limbah (IPAL).

Berdasarkan permasalahan sanitasi tersebut maka perlu adanya sistem pengelolaan air limbah domestik yang sesuai dengan kondisi Kecamatan Mamasa untuk 20 tahun ke depan. Penelitian ini memberikan gambaran tentangcara menentukan wilayah prioritas pembangunan sistem pengelolaan air limbah domestik di Kecamatan Mamasa. Sehingga perencanaan tersebut sesuai dan tepat sasaran untuk meningkatkan pelayanan di bidang air limbah yang komprehensif dan lebih update terhadap perubahan-perubahan yang ada.

\section{TINJUAN PUSTAKA}

\section{Air Limbah Domestik}

Menurut Notoatmodjo (2007), air limbah yang bersumber dari rumah tangga merupakan buangan yang berasal dari pemukiman penduduk. Pada umumnya airlimbah terdiri dari excreta (tinja dan air seni), air bekas cucian dapur dankamar mandi dan umumnya terdiri dari bahan-bahan organik. Menurut Ehlers and Steel dalam Asmadi dan Suharno (2012:4), air limbah yaitu cairan yang dibawa oleh saluran air buangan. Sedangkan menurut Asmadi dan Suharno (2012:4) limbah cair adalah cairan buangan yang berasal dari rumah tangga, perdagangan, perkantoran, industri maupun tempat-tempat umum lainnya yang biasanya mengandung bahan-bahan atau zat-zat yang dapat membahayakan kesehatan atau kehidupan manusia serta mengganngu kelestarian lingkungan hidup.

Secara kualitatif limbah rumah tangga sebagian besar terdiri dari zat organik baik berupa padatan maupun cair, garam, lemak dan bakteri, khususnya bakteri golongan E. Coli, jasad patogen dan parasit (Asis dalam Nurmayanti, 2002).Air buangan perlu pengelolaan, karena apabila airbuangan ini tidak dikelola secara baik akan dapat menimbulkan gangguan, baik terhahap lingkungan maupun terhadap lingkungan maupun terhadapkehidupan yang ada (Sugiharto, 2008:45).

\section{Pengelolaan Air Limbah}

Menurut Alaerts, 1984 dalam Rhomaidhi, (2008: 22) menyatakan jenis dan macam air limbah dikelompokkan berdasarkan sumber penghasilan atau penyebab air limbah. Terdapat tiga sistem pengolahan air limbah domestik yang meliputi

Cara pengelolaan air limbah tersedia 2 cara :

1) Air limbah sistem setempat (yang umum digunakan sekarang di setiap rumah yaitu Tangki Septik/Cubluk + bidang resapan) atau sekarang dikenal dengan istilah SPAL-S.

2) Air limbah terpusat (sistem jaringan pipa dan pengolahan IPAL).

3) Sistem Komunal. Pengelolaan air limbah domestik dengan sistem septictank komunal

Menentukan sistem air limbah terpusat memerlukan pendekatan tertentu (Wulandari, 2014). Dalam menentukan teknologi perlu terlebih dahulu ditentukan zona air limbah, kemudian karakteristik setiap zona dapat disesuaikan teknologi yang layak. Untuk penentuan zona ada beberapa parameter yang mesti dipertimbangkan. Parameter yang diuji ada 9 (sembilan) sebagai berikut:

1) Kepadatan Penduduk

1) Kawasan sentral bisnis

2) Sumber air bersih

3) Sumber air permukaan

4) Kedalaman air tanah

5) Permeabilitas tanah

6) Kemiringan tanah

7) Ketersediaan lahan

8) Kemampuan membiayai/kecocokan 


\section{Sistem Pembuangan Air Limbah Terpusat (Off- Site Sanitation)}

Sistem pengelolaan air limbah permukiman terpusat terdiri dari unit pelayanan (sambungan rumah), unit pengumpulan, unit pengolahan dan unit pengolahan lumpur. Unit pelayanan berfungsi untuk mengumpulkan air limbah (black water dan grey water) dari setiap rumah dan menyalurkannya ke dalam unit pengumpulan. Unit ini terdiri dari sambungan rumah dan inspectionchamber. Sambungan rumah yang termasuk dalam unit pelayanan meliputi : pipa dari kloset, bak penagkap lemak dari oulet air dapur, bak kontrol di pekarangan, pipa sambungan rumah dari bak kontrol ke bak inspeksi, bak Inspeksi di luar pagar pekarangan.

Unit pengumpulan berfungsi untuk menyalurkan air limbah dari tiap unit pelayanan melalui jaringan pipa menuju Instalasi Pengolahan Air Limbah (IPAL). Unit pengumpulan terdiri dari: pipa lateral, pipa utama, pipa trunk, manhole, siphon, terminal cleanout, pompa, listrik dan peralatannya. Unit pengolahan berfungsi untuk mengolah air limbah yang masuk ke dalam IPAL. Unit pengolahan terdiri dari pengolahan fisik dan pengolahan biologis. Pengolahan biologis meliputi pengolahan secara aerob, anaerob dan kombinasi keduanya. Sedangkan pengolahan kimiawi meliputi netralisasi, presipitasi, koagulasi dan flokulasi (Siregar, 2005).

\section{Sistem Pembuangan Air Limbah Setempat (On- Site Sanitation)}

Sanitasi sistem setempat (on-site) yaitu sistem dimana fasilitas pengolahan air limbah berada dalam persil atau batas tanah yang dimiliki, fasilitas ini merupakan fasilitas sanitasi individual seperti septik tank atau cubluk. Pada sistem on-site ada 2 jenis sarana yang dapat diterapkan yakni sistem individual dan komunal. Pada skala invidual sarana yang digunakan adalah septik dengan varian pada pengolahan lanjutan untuk effluentnya yakni : dengan bidang resapan, dialirkan pada small bore sewer, dengan evapotranspirasi atau menggunakan filter.

Sistem Komunal menggunakan MCK atau Tangki Septi Komunal dengan $<100$ jiwa. Komponen SPAL-S untuk kepadatan > 100 - < 300 jiwa/ha, komponennnya Tangki Septik Individu, Tangki Septik Komunal, dan MCK Komunal. Sedangkan tinja dari septik tank akan diangkut menggunakan truk penyedot tinja dan diolah di IPLT (Instalasi Pengolahan Lumpur Tinja). Sarana sistem setempat (SPAL-S) dengan kepadatan < $100 \mathrm{jiwa/} \mathrm{ha} \mathrm{dapat} \mathrm{menggunakan} \mathrm{1)}$ Cubluk Tunggal, 2) Cubluk Kembar.

\section{Pengolahan Air Limbah Secara Biologis}

Proses pengolahan air limbah dengantujuan untuk menurunkan atau menyisihkansubtrat tertentu yang terkandung dalam airdengan memanfaatkan aktifitas mikro-organismebiasa disebut dengan proses biologis. Prosespengolahan air limbahsecarabiologismerupakan suatu proses biokimia yang dapatberlangsung dalam dua lingkungan, yaitulingkungan anaerob (tanpa udara) dan aerob(dengan udara) (Manurung, 2004).

Kondisi aerob, yaitu kondisidimana kandungan oksigen terlarut (DO) didalam air cukupbesar, sehingga keberadaanoksigen merupakan faktor pembatas. Sedangkankondisi anaerob merupakan kebalikan darikondisi aerob, dimana pada kondisi inikandungan oksigen terlarut sangat rendah ataudapat dikatakan tidak terdapat oksigen. Proses biologis aerob biasanya digunakan untukpengolahan air limbah dengan beban BOD yangtidak terlalu besar, sedangakan proses biologisanaerobik digunakan untuk pengolahan air limbah dengan beban BOD yang sangat tingi (Darsono, 2007). Pengolahan air limbah secara biologis secara garis besar dapat dibagi menjadi tiga 3), yaitu proses biologis dengan biakan tersuspensi (suspended culture), proses biologis dengan biakan melekat (attached culture) dan proses pengolahan dengan sistem kolam (lagoon). 


\section{Instalasi Pengolahan Air Limbah (IPAL) Komunal}

Sistem sanitasi terpadu dibutuhkan mengingat keterbatasan lahan perumahan dan kurangnya pemahaman akan sanitasi yang baik suatu permukiman. Instalasi Pengelolaan Air Limbah (IPAL) dibuat secara terpadu yang digunakan untuk menampung air limbah sejumlah rumah tangga (Rhomaidhi, 2008: 23).

Sistem ini dilakukan untuk menangani limbah domestik pada wilayah yang tidak memungkinkan untuk dilayani oleh sistem terpusat ataupun secara individual. Penanganan dilakukan pada sebagian wilayah dari suatu kota, dimana setiap rumah tangga yang mempunyai fasilitas MCK pribadi menghubungkan saluran pembuangan ke dalam sistem perpipaan air limbah untuk dialirkan menuju instalasi pengolahan limbah komunal. Untuk sistem yang lebih kecil dapat melayani 2-5 rumah tangga, sedangkan untuk sistem komunal dapat melayani 10-100 rumah tangga atau bahkan dapat lebih. Effluent dari instalasi pengolahan dapat disalurkan menuju sumur resapan atau juga dapat langsung dibuang ke badan air (sungai). Fasilitas sistem komunal dibangun untuk melayani kelompok rumah tangga atau MCK umum. Bangunan pengolahan air limbah ini dapat diterapkan di perkampungan dimana tidak memungkinkan bagi warga masyarakatnya untuk membangun septictank individual di rumahya masing-masing (Rhomaidhi, 2008: 32).

\section{Metode Skoring dan Pembobotan}

Metode skoring adalah suatu metode pemberian skor atau nilai terhadap masing - masing value parameter untuk menentukan tingkat kemampuannya. penilaian ini berdasarkan kriteria yang telah ditentukan. Sedangakan metode pembobotan atau disebut juga weighting adalah suatu metode yang digunakan apabila setiap karakter memiliki peranan berbeda atau jika memiliki beberapa parameter untuk mementukan kemampuan lahan atau sejenisnya (Muhammad, 2015).

\section{METODOLOGI}

Pengumpulan Data meliputi

a) Persiapan Logistik

b) Persiapan Supervisor

c) Pelaksanaan survey

Setelah survey dilakukan, selanjutnya data yang telah dikumpulkan, dimasukkan dan dikumpulkan menjadi satu untuk diolah. Data yang dikumpulkan meliputi data kondisi daerah rencana, data kondisi eksisting sistem pengelolaan air limbah, dan data permasalahan yang dihadapi.

Cara pengumpulan dan analisis data dapat dilakukan sebagai berikut :

1. Pengumpulan dan Analisis Data Primer pengumpulan data yang dilakukan melalui pekerjaan survey secara langsung ke lokasi pengelolaan air limbah pengambilan sampling

2. Pengumpulan dan Analisis Data Sekunder pengumpulan data yang sudah ada, baik berupa data statistik, data hasil survei dan studi terkait serta kebijakan dan pengaturan. Selanjutnya dilakukan analisis untuk proyeksi kebutuhan sesuai periode perencanaan.

3. Penentuan Zona Perencanaan

Bertujuan untuk membagi daerah perencanaan menjadi beberapa zona menurut jenis pengelolaan air limbah. Metode yang digunakan untuk pembagian zona perencanaan adalah metode skoring dan pemetaan (overlay) daerah perencanaan berdasarkan kriteria tertentu.

4. Penentuan Zona Prioritas

Bertujuan untuk membagi zona perencanaan menurut tingkat kemendesakan/ tingkat prioritas dalam pengelolaan air limbah. Metode yang digunakan untuk pembagian zona prioritas adalah metode pembobotan dan pemetaan zona perencanaan berdasarkan kriteria tertentu

\section{HASIL DAN PEMBAHASAN}

Secara geografis letak wilayah Kabupaten Mamasa berada pada koordinat antara $119^{\circ} 00^{\prime} 49^{\prime \prime}$ 119³2’27' Bujur Timur, serta $2^{\circ} 40^{\prime} 00^{\prime}$ ' hingga 
03ำ' 00 Lintang Selatan dengan luas wilayah seluas $\pm 3005,88 \mathrm{~km} 2$.Secara administratif, Kabupaten Mamasa sampai pada saat ini terdiri dari 17 (tujuh belas) wilayah kecamatan.Air limbah yang ada di Kabupaten Mamasa berasal dari air kotor yang ditimbulkan dari rumah tangga yang disebut limbah air kotor domestik dan air kotor yang dihasilkan dari buangan kegiatan ekonomi, industri masyarakat, kegiatan pertanian disebut air kotor non domestik. Berdasarkan hasil analisis produksi limbah cair yang diperoleh dari penggunaan masyarakat setempat untuk masa yang akan datang diketahui bahwa, intensitas terhadap produksi limbah cair semakin meningkat pada tahun perencanaan. Produksi air limbah di Kabupaten Mamasa hingga 20 tahun kedepan berdasarkan analisa diperkirakan dapat mencapai 101.084 sampai 1.167 .367 lt/hari.

\section{Penentuan Zona Perencanaan}

Penentuan zona perencanaan bertujuan untuk membagi daerah perencanaan menjadi beberapa zona menurut jenis pengelolaan air limbah. Metode yang digunakan untuk pembagian zona perencanaan adalah metode skoring dan pemetaan (overlay) daerah perencanaan berdasarkan kriteria tertentu. Kriteria yang digunakan dalam penentuan zona perencanaan adalah:

1. Tingkat kepadatan penduduk,

Mengidentifikasi kepadatan penduduk per desa/ kelurahan yang memiliki nilai kepadatan penduduk hampir sama, dikelompokkan berdasarkan keseragaman nilainya.

2. Bentuk topografi dan kemiringan lahan,

Mengidentifikasi kawasan yang bentuk topografi dan kemiringannya seirama (tidak mendadak curam dari datar).

3. Tingkat kepadatan bangunan,

Mengidentifikasi jumlah rumah dan luas kawasan perumahan untuk menghitung kepadatan bangunan, kemudian mengelompokkan kepadatan yang hampir sama mendekati seragam menjadi satu zona perencanaan.

4. Tingkat permasalahan pencemaran air tanah dan air permukaan,

Mengidentifikasi kawasan yang sudah tercemar air tanah dan air permukaan, kemudian dikelompokkan menjadi satu zona perencanaan.

5. Kesamaan badan air,
Mengidentifikasi badan air penerima dan kaitkan dengan kawasan zona perencanaan diatas.

6. Pertimbangan batas administrasi.

Mengidentifikasi batas administrasi tiap kelurahan/ desa sebagai pertimbangan terhadap simulasi zona perencanaan yang sudah dioverlay sebelumnya

Masing-masing kriteria tersebut diberi ranking/ skor berdasarkan urutan kesesuaian zona perencanaan berdasarkan jenis pengelolaan air limbah. Khusus untuk pertimbangan batas administrasi diarahkan menggunakan batas desa/ kelurahan sehingga mempermudah dalam pengelolaan air limbah skala desa/ kelurahan. berikut penjelasan mengenai perangkingan dan mapping masing-masing kriteria.

1. Perangkingan dan Mapping berdasarkan Tingkat Kepadatan Penduduk

Metode perangkingan berdasarkan perhitungan angka kepadatan penduduk, dengan pendekatan sebagai berikut :

a. Nilai 1 diberikan apabila angka kepadatan penduduk yang rendah, yaitu berada pada range $<100 \mathrm{jiwa} / \mathrm{ha}$.

b. Nilai 2 diberikan apabila angka kepadatan penduduk sedang, yaitu berada pada range 100$200 \mathrm{jiwa} / \mathrm{ha}$.

c. Nilai 3 diberikan apabila angka kepadatan penduduk diperoleh tinggi, yaitu berada pada range 201-300 jiwa/ha.

d. Nilai 4 diberikan apabila angka kepadatan penduduk diperoleh sangat tinggi, yaitu berada pada kepadatan $>300 \mathrm{jiwa} / \mathrm{ha}$.

Untuk perangkingan daerah perencanaan berdasarkan angka kepadatan penduduk dapat dilihat pada tabel berikut.

Tabel $\begin{gathered}\text { 1.Perangkingan } \\ \text { Berdasarkan } \\ \text { Penduduk }\end{gathered} \quad \begin{array}{rr}\text { Daerah } \\ \text { Angka }\end{array} \quad \begin{array}{r}\text { Perencanaan } \\ \text { Kepadatan }\end{array}$

\begin{tabular}{|l|c|c|c|c|}
\hline \multirow{2}{*}{ Desa/Kelurahan } & \multicolumn{4}{|c|}{ Proyeksi 2036 } \\
\cline { 2 - 5 } & $\begin{array}{c}\text { Jml Pddk } \\
\text { (jw) }\end{array}$ & L (Ha) & $\begin{array}{c}\text { Kepadatan } \\
\text { (jw/Ha) }\end{array}$ & SKOR \\
\hline Mamasa & 6.169 & 38,87 & 159 & 2 \\
\hline Osango & 4.365 & 18,74 & 233 & 3 \\
\hline Rambu saratu & 2.422 & 26,52 & 91 & 1 \\
\hline Lambanan & 4.007 & 55,51 & 72 & 1 \\
\hline $\begin{array}{l}\text { Lembangna } \\
\text { Salulo }\end{array}$ & 841 & 21,53 & 39 & 1 \\
\hline Taupe & 1.852 & 41,16 & 45 & 1 \\
\hline Buntu Buda & 3.652 & 25,29 & 144 & 2 \\
\hline Tondok Bakaru & 2.417 & 26,52 & 91 & 1 \\
\hline Pebassian & 679 & 29,43 & 23 & 1 \\
\hline
\end{tabular}




\begin{tabular}{|l|c|c|c|c|}
\hline \multirow{2}{*}{ Desa/Kelurahan } & \multicolumn{4}{|c|}{ Proyeksi 2036 } \\
\cline { 2 - 5 } & $\begin{array}{c}\text { Jml Pddk } \\
\text { (jw) }\end{array}$ & L (Ha) & $\begin{array}{c}\text { Kepadatan } \\
\text { (jw/Ha) }\end{array}$ & SKOR \\
\hline Mambulilling & 970 & 9,61 & 101 & 2 \\
\hline $\begin{array}{l}\text { Bombong } \\
\text { Lambe }\end{array}$ & 1.266 & 19,79 & 64 & 1 \\
\hline Bubun batu & 1.046 & 12,66 & 83 & 1 \\
\hline & 29.686 & 325,62 & 91 & \\
\hline
\end{tabular}

2. Perangkingan dan Mapping berdasarkan Bentuk Topografi dan Kemiringan Lahan

Metode perangkingan berdasarkan kondisi topografi, dengan pendekatan sebagai berikut:

a. Nilai 1 diberikan apabila kondisi topografi rendah, yaitu berada pada range $<1000 \mathrm{mdpl}$.

b. Nilai 2 diberikan apabila kondisi topografi sedang, yaitu berada pada range 1000-2000 mdpl.

c. Nilai 3 diberikan apabila kondisi topografi tinggi, yaitu berada pada range >2000-3000 mdpl.

d. Nilai 4 diberikan apabila kondisi topografi sangat tinggi, yaitu berada pada range $>3000$ mdpl.

Untuk perangkingan daerah perencanaan berdasarkan kondisi topografi dapat dilihat pada tabel berikut.

Tabel 2.Perangkingan Daerah Perencanaan Berdasarkan Kondisi Topografi

\begin{tabular}{|l|c|c|}
\hline \multicolumn{1}{|c|}{ Desa/Kelurahan } & Topografi & SKOR \\
\hline Mamasa & $<1000$ & 1 \\
\hline Osango & $<1000$ & 1 \\
\hline Rambu saratu & $1250-2000$ & 2 \\
\hline Lambanan & $1250-2000$ & 2 \\
\hline Lembangna Salulo & $<1000$ & 1 \\
\hline Taupe & $1250-2000$ & 2 \\
\hline Buntu Buda & $<1000$ & 1 \\
\hline Tondok Bakaru & $<1000$ & 1 \\
\hline Pebassian & $1250-2000$ & 2 \\
\hline Mambulilling & $1250-2000$ & 2 \\
\hline Bombong Lambe & $<1000$ & 1 \\
\hline Bubun batu & $1250-2000$ & 2 \\
\hline
\end{tabular}

3. Perangkingan dan Mapping berdasarkan Tingkat Kepadatan Bangunan

Metode perangkingan berdasarkan kepadatan bangunan, dengan pendekatan sebagai berikut:

a. Nilai 1 diberikan apabila kepadatan bangunan netto antara 1-20 unit/ha.

b. Nilai 2 diberikan apabila kepadatan bangunan netto antara 21-40 unit/ha.

c. Nilai 3 diberikan apabila kepadatan bangunan netto antara 41-60 unit/ha. d. Nilai 4 diberikan apabila kepadatan bangunan netto antara 61-80 unit/ha.

Untuk perangkingan daerah perencanaan berdasarkan kepadatan penduduk dapat dilihat pada tabel berikut.

Tabel 3Perangkingan Daerah Perencanaan Berdasarkan Kepadatan Penduduk

\begin{tabular}{|l|c|c|c|c|}
\hline \multirow{2}{*}{ Desa/Kelurahan } & $\begin{array}{c}\text { Jml } \\
\text { Bangunan }\end{array}$ & $\begin{array}{c}\text { L } \\
\text { Perkim }\end{array}$ & $\begin{array}{c}\text { Kepadatan } \\
\text { bangunan }\end{array}$ & \multirow{2}{*}{ SKOR } \\
\cline { 2 - 5 } & $\begin{array}{c}\mathbf{2 0 3 6} \\
\text { (unit) }\end{array}$ & (Ha) & (unit/ha) & \\
\hline Mamasa & 987 & 38,87 & 25 & 2 \\
\hline Osango & 698 & 18,74 & 37 & 2 \\
\hline Rambu saratu & 388 & 26,52 & 15 & 1 \\
\hline Lambanan & 641 & 55,51 & 12 & 1 \\
\hline $\begin{array}{l}\text { Lembangna } \\
\text { Salulo }\end{array}$ & 135 & 21,53 & 6 & 1 \\
\hline Taupe & 296 & 41,16 & 7 & 1 \\
\hline Buntu Buda & 584 & 25,29 & 23 & 2 \\
\hline Tondok Bakaru & 387 & 26,52 & 15 & 1 \\
\hline Pebassian & 109 & 29,43 & 4 & 1 \\
\hline Mambulilling & 155 & 9,61 & 16 & 1 \\
\hline $\begin{array}{l}\text { Bombong } \\
\text { Lambe }\end{array}$ & 203 & 19,79 & 10 & 1 \\
\hline Bubun batu & 167 & 12,66 & 13 & 1 \\
\hline
\end{tabular}

4. Perangkingan dan Mapping berdasarkan Tingkat Permasalahan Pencemaran Air Tanah dan Air Permukaan

Metode perangkingan berdasarkan tingkat pencemaran air permukaan, dengan pendekatan sebagai berikut:

a. Nilai 1 diberikan apabila tingkat pencemaran air permukaan relatif rendah yaitu $\mathrm{pH}$ dan amoniak tinggi.

b. Nilai 2 diberikan apabila tingkat pencemaran air permukaan sedang yaitu $\mathrm{pH}$, amoniak dan khlorida tinggi.

c. Nilai 3 diberikan apabila tingkat pencemaran air permukaan buruk yaitu $\mathrm{pH}$, amoniak, khlorida, dan kekeruhan tinggi.

d. Nilai 4 diberikan apabila tingkat pencemaran air permukaan sangat buruk yaitu $\mathrm{pH}$, amoniak, khlorida, kekeruhan dan kesadahan tinggi.

Untuk perangkingan daerah perencanaan berdasarkan tingkat pencemaran air permukaan dapat dilihat pada tabel berikut. 
Tabel 4.Perangkingan Daerah Perencanaan Berdasarkan Tingkat Pencemaran Air Permukaan

\begin{tabular}{|l|l|c|}
\hline \multicolumn{1}{|c|}{ Desa/Kelurahan } & \multicolumn{1}{|c|}{$\begin{array}{c}\text { Tingkat pencemaran air } \\
\text { permukaan }\end{array}$} & SKOR \\
\hline Mamasa & $\begin{array}{l}\text { ph, amoniak, khlorida tinggi, } \\
\text { kekeruhan tinggi }\end{array}$ & 4 \\
\hline Osango & $\begin{array}{l}\text { ph, amoniak, khlorida, } \\
\text { kekeruhan, kesadahan tinggi }\end{array}$ & 4 \\
\hline Rambu saratu & ph, amoniak, khlorida tinggi & 2 \\
\hline Lambanan & ph, amoniak, khlorida tinggi & 2 \\
\hline Lembangna Salulo & ph, amoniak, khlorida tinggi & 2 \\
\hline Taupe & ph, amoniak, khlorida tinggi & 2 \\
\hline Buntu Buda & ph, amoniak, khlorida tinggi & 2 \\
\hline Tondok Bakaru & ph, amoniak, khlorida tinggi & 2 \\
\hline Pebassian & ph, amoniak, khlorida tinggi & 2 \\
\hline Mambulilling & ph, amoniak, khlorida tinggi & 2 \\
\hline Bombong Lambe & $\begin{array}{l}\text { ph, amoniak, khlorida tinggi } \\
\text { ph, amoniak, khlorida tinggi }\end{array}$ & 2 \\
\hline Bubun batu & & 2 \\
\hline
\end{tabular}

5. Perangkingan dan Mapping berdasarkan Kesamaan Badan Air Penerima

Metode perangkingan berdasarkan kesamaan badan air, dengan pendekatan sebagai berikut:

a. Nilai 1 diberikan apabila tidak memiliki kesamaan badan air.

b. Nilai 2 diberikan apabila memiliki kesamaan badan air.

Untuk perangkingan daerah perencanaan berdasarkan kesamaan badan air dapat dilihat pada tabel berikut.

Tabel 5.Perangkingan Daerah Perencanaan Berdasarkan Kesamaan Badan Air

\begin{tabular}{|l|c|}
\hline \multicolumn{1}{|c|}{ Desa/Kelurahan } & Skor \\
\hline Mamasa & 2 \\
\hline Osango & 2 \\
\hline Rambu saratu & 2 \\
\hline Lambanan & 2 \\
\hline Lembangna Salulo & 2 \\
\hline Taupe & 2 \\
\hline Buntu Buda & 2 \\
\hline Tondok Bakaru & 2 \\
\hline Pebassian & 2 \\
\hline Mambulilling & 2 \\
\hline Bombong Lambe & 2 \\
\hline
\end{tabular}

\begin{tabular}{|c|c|}
\hline Desa/Kelurahan & Skor \\
\hline Bubun batu & 2 \\
\hline
\end{tabular}

Dari hasil perangkingan seluruh kriteria tersebut kemudian dijumlahkan totalnya. Rata-rata nilai skor kemudian diklasifikasikan menjadi zona perencanaan, seperti yang terlihat pada tabel dibawah ini.

Tabel 6. Klasifikasi zona pengelolaan air limbah

\begin{tabular}{|l|l|l|}
\hline $\begin{array}{c}\text { Klasifikasi zona } \\
\text { pengelolaan air } \\
\text { limbah }\end{array}$ & \multicolumn{1}{|c|}{$\begin{array}{c}\text { Rata-rata } \\
\text { skor }\end{array}$} & $\begin{array}{c}\text { Arahan Pengelolaan Air } \\
\text { Limbah }\end{array}$ \\
\hline Zona A & $>3,00-4,00$ & SPAL-T skala kab/kota \\
\hline Zona B & $>2,00-3,00$ & SPAL-T skala kawasan \\
\hline Zona C & $>1,00-2,00$ & SPAL-S tangki septik \\
\hline Zona D & $0-1,00$ & SPAL-S cubluk \\
\hline
\end{tabular}

Dari hasil penilaian rata-rata skor maka dapat diketahui bahwa di Kecamatan Mamasa belum memerlukan SPAL-T skala kota. Sebagian besar sistem pengelolaan limbah domestik dapat dilayani dengan SPAL-setempat dengan tangki septik. Desa/ kelurahan yang memerlukan SPAL terpusat skala kawasan ada 2 desa/ kelurahan, yaitu Desa/Kelurahan Mamasa dan Osango.

\section{Penentuan Zona Prioritas}

Penentuan zona prioritas bertujuan untuk membagi zona perencanaan menurut tingkat kemendesakan/ tingkat prioritas dalam pengelolaan air limbah. Metode yang digunakan untuk pembagian zona prioritas adalah metode pembobotan dan pemetaan zona perencanaan berdasarkan kriteria tertentu. Kriteria yang digunakan dalam penentuan zona prioritas adalah:

1. Tingkat kepadatan penduduk

Kepadatan penduduk adalah perbandingan antara jumlah penduduk dengan luas wilayah. Dalam perhitungan kepadatan penduduk digunakan rumus kepadatan penduduk neto untuk proyeksi penduduk tahun 2036. Sehingga data yang dipergunakan untuk perhitungan adalah data proyeksi jumlah penduduk tahun 2036 dibandingkan dengan data luas lahan permukiman. Semakin tinggi tingkat kepadatan penduduk maka semakin tinggi tingkat prioritas untuk pengelolaan air limbah.

2. Bentuk topografi

Indikator yang digunakan adalah kondisi topografi. Semakin tinggi topografi maka semakin 
mudah dalam pembuatan sistem pengelolaan air limbah, sehingga topografi yang tinggi akan mendapat nilai lebih tinggi.

3. Angka kesakitan penyakit

Indikator yang digunakan adalah jumlah penduduk yang menderita penyakit (terutama penyakit akibat kondisi sanitasi yang buruk) pada suatu desa/ kelurahan. Semakin banyak jumlah penduduk yang menderita penyakit maka mendapat nilai skor lebih tinggi.

4. Tingkat Pencemaran Air Permukaan

Indikator yang digunakan adalah hasil penelitian beberapa sampel yang diambil dari sungai. Tingkat pencemaran air permukaan yang tinggi akan mempengaruhi kualitas pengelolaan air limbah, sehingga jika tingkat pencemaran air permukaan tinggi maka mendapat nilai lebih rendah.

5. Tingkat kemampuan ekonomi masyarakat

Indikator yang digunakan adalah prosentase jumlah keluarga menurut pentahapan keluarga sejahtera. Tingkat kemampuan ekonomi masyarakat akan berpengaruh terhadap pembiayaan dan pemeliharaan bangunan sistem pengelolaan air limbah, sehingga masyarakat yang memiliki dominasi kemampuan ekonomi lebih tinggi akan mendapat nilai lebih tinggi pula.

6. Kondisi Sanitasi

Indikator yang digunakan adalah prosentase jumlah penduduk terlayani jamban sehat. Kepemilikan jamban akan mempermudah dalam pembuatan instalasi sistem pengelolaan air limbah, sehingga masyarakat yang memiliki tingkat kepemilikan jamban tinggi maka akan mendapat nilai lebih tinggi.

7. Tingkat kemauan masyarakat menerima teknologi air limbah

Indikator yang digunakan adalah besarnya kemauan masyarakat dalam menerima, menggunakan dan memelihara bangunan pengelola air limbah. Termasuk dukungan pemerintah daerah dalam pembangunan sistem pengelolaan air limbah. Jika kemauan masyarakat menerima teknologi air limbah tinggi, didukung oleh kebijakan pemerintah daerah maka akan mendapat skor lebih tinggi.

8. Tingkat ketersediaan PDAM

Indikator yang digunakan adalah jumlah rumah tangga yang sudah mendapat pelayanan air bersih dari PDAM. Jika masyarakat yang terlayani air bersih dari PDAM lebih banyak maka akan mendapat skor lebih tinggi.

Masing-masing kriteria diberi bobot sesuai dengan tingkat prioritas dalam penentuan zona perencanaan, yaitu:

Tabel 7. Kriteria bobot sesuai dengan tingkat prioritas dalam penentuan zona perencanaan

\begin{tabular}{|l|l|l|}
\hline No & Kriteria & Bobot \\
\hline 1. & Tingkat kepadatan penduduk & $20 \%$ \\
\hline 2. & Bentuk topografi & $5 \%$ \\
\hline 3. & Angka kesakitan penyakit & $5 \%$ \\
\hline 4. & Tingkat pencemaran air permukaan & $5 \%$ \\
\hline 5. & $\begin{array}{l}\text { Tingkat kemampuan ekonomi } \\
\text { masyarakat }\end{array}$ & $20 \%$ \\
\hline 6. & Kondisi sanitasi kemauan masyarakat & $10 \%$ \\
\hline 7. & $\begin{array}{l}\text { Tingkat } \\
\text { menerima teknologi air limbah }\end{array}$ & $5 \%$ \\
\hline 8. & Tingkat ketersediaan PDAM \\
\hline
\end{tabular}

Penilaian zona perencanaan adalah dengan cara memberikan skor/ ranking terhadap kriteria yang telah ditentukan, kemudian dikalikan dengan bobot masing-masing kriteria. Untuk pemberian skor tingkat kepadatan penduduk, dan bentuk topografinsudah dilakukan pada tahap penentuan zona perencanaan sehingga tinggal dikalikan dengan bobotnya. Sedangkan kriteria lainnya dilakukan perangkingan dan mapping sebagai berikut:

1. Perangkingan dan Mapping berdasarkan Angka Kesakitan Penyakit

Metode perangkingan berdasarkan angka kesakitan penyakit, dengan pendekatan sebagai berikut:

a. Nilai 1 diberikan apabila angka kesakitan penyakit 1-31 jiwa.

b. Nilai 2 diberikan apabila angka kesakitan penyakit 32-63 jiwa.

c. Nilai 3 diberikan apabila angka kesakitan penyakit 64-95 jiwa.

d. Nilai 4 diberikan apabila angka kesakitan penyakit 96-125 jiwa.

Untuk perangkingan daerah perencanaan berdasarkan angka kesakitan penyakit dapat dilihat pada tabel berikut. 
Tabel 8.Perangkingan Daerah Perencanaan Berdasarkan Angka Kesakitan

Penyakit

\begin{tabular}{|c|c|c|c|}
\hline Desa/Kelurahan & $\begin{array}{c}\text { Jml Pddk } \\
(\text { jw })\end{array}$ & $\begin{array}{c}\text { Jml Sakit } \\
(\text { jw })\end{array}$ & Skor \\
\hline Mamasa & 5.137 & 51 & 2 \\
\hline Osango & 3.635 & 36 & 2 \\
\hline Rambu saratu & 2.017 & 20 & 1 \\
\hline Lambanan & 3.337 & 33 & 2 \\
\hline Lembangna Salulo & 700 & 7 & 1 \\
\hline Taupe & 1.542 & 15 & 1 \\
\hline Buntu Buda & 3.041 & 30 & 1 \\
\hline Tondok Bakaru & 2.013 & 20 & 1 \\
\hline Pebassian & 565 & 6 & 1 \\
\hline Mambulilling & 808 & 8 & 1 \\
\hline Bombong Lambe & 1.054 & 11 & 1 \\
\hline Bubun batu & 871 & 9 & 1 \\
\hline
\end{tabular}

2. Perangkingan dan Mapping berdasarkan Tingkat Pencemaran Air Permukaan

Metode perangkingan berdasarkan tingkat pencemaran air permukaan, dengan pendekatan sebagai berikut:

a. Nilai 1 diberikan apabila angka BOD sangat tinggi $\geq 3 \mathrm{~kg} / \mathrm{hr} / \mathrm{ha}$.

b. Nilai 2 diberikan apabila angka BOD sangat tinggi $2-\geq 3 \mathrm{~kg} / \mathrm{hr} / \mathrm{ha}$.

c. Nilai 3 diberikan apabila angka BOD sangat tinggi $\geq 3 \mathrm{~kg} / \mathrm{hr} / \mathrm{ha}$.

d. Nilai 4 diberikan apabila angka BOD sangat tinggi $\geq 3 \mathrm{~kg} / \mathrm{hr} / \mathrm{ha}$.

Untuk perangkingan daerah perencanaan berdasarkan tingkat pencemaran air permukaan dapat dilihat pada tabel berikut.

Tabel 9.Perangkingan Daerah Perencanaan Berdasarkan Tingkat Pencemaran Air Permukaan

\begin{tabular}{|l|c|r|r|r|}
\hline \multicolumn{1}{|c|}{ Desa/Kelurahan } & $\begin{array}{c}\text { Jml } \\
\text { Pddk } \\
\text { (jw) }\end{array}$ & $\begin{array}{c}\text { Kepadatan } \\
\text { penduduk } \\
\text { netto (jw/Ha) }\end{array}$ & $\begin{array}{c}\text { Angka } \\
\text { BOD }\end{array}$ & Skor \\
\hline Mamasa & 5.137 & 147 & 8 & 1 \\
\hline Osango & 3.635 & 227 & 13 & 1 \\
\hline Rambu saratu & 2.017 & 81 & 5 & 1 \\
\hline Lambanan & 3.337 & 63 & 4 & 1 \\
\hline Lembangna Salulo & 700 & 33 & 2 & 2 \\
\hline
\end{tabular}

\begin{tabular}{|l|r|r|r|r|}
\hline \multicolumn{1}{|c|}{ Desa/Kelurahan } & $\begin{array}{c}\text { Jml } \\
\text { Pddk } \\
(\mathbf{j w})\end{array}$ & $\begin{array}{c}\text { Kepadatan } \\
\text { penduduk } \\
\text { netto (jw/Ha) }\end{array}$ & $\begin{array}{c}\text { Angka } \\
\text { BOD }\end{array}$ & Skor \\
\hline Taupe & 1.542 & 39 & 2 & 2 \\
\hline Buntu Buda & 3.041 & 132 & 7 & 1 \\
\hline Tondok Bakaru & 2.013 & 81 & 5 & 1 \\
\hline Pebassian & 565 & 19 & 1 & 3 \\
\hline Mambulilling & 808 & 90 & 5 & 1 \\
\hline Bombong Lambe & 1.054 & 55 & 3 & 1 \\
\hline Bubun batu & 871 & 73 & 4 & 1 \\
\hline
\end{tabular}

3. Perangkingan dan Mapping berdasarkan Tingkat Kemampuan Ekonomi Masyarakat

Metode perangkingan berdasarkan tingkat kemampuan ekonomi masyarakat, dengan pendekatan sebagai berikut:

a. Nilai 1 diberikan apabila prosentase jumlah KK sejahtera rendah yaitu $<25 \%$.

b. Nilai 2 diberikan apabila prosentase jumlah KK sejahtera sedang yaitu $25-50 \%$.

c. Nilai 3 diberikan apabila prosentase jumlah KK sejahtera tinggi yaitu $51-75 \%$.

d. Nilai 4 diberikan apabila prosentase jumlah KK sejahtera sangat tinggi yaitu $>75 \%$.

Untuk perangkingan daerah perencanaan berdasarkan tingkat kemampuan ekonomi masyarakat dapat dilihat pada tabel berikut.

Tabel 10.Perangkingan Daerah Perencanaan Berdasarkan Tingkat Kemampuan Ekonomi

\begin{tabular}{|l|r|r|r|r|}
\hline Desa/Kelurahan & \multicolumn{1}{|c|}{ JML KK } & $\begin{array}{c}\text { KK } \\
\text { sejahtera }\end{array}$ & \multicolumn{1}{c|}{$\%$} & SKOR \\
\hline Mamasa & 628 & 549 & $87 \%$ & 4 \\
\hline Osango & 530 & 396 & $75 \%$ & 3 \\
\hline Rambu saratu & 461 & 335 & $73 \%$ & 3 \\
\hline Lambanan & 483 & 411 & $85 \%$ & 4 \\
\hline Lembangna Salulo & 169 & 160 & $95 \%$ & 4 \\
\hline Taupe & 391 & 310 & $79 \%$ & 4 \\
\hline Buntu Buda & 302 & 238 & $79 \%$ & 4 \\
\hline Tondok Bakaru & 394 & 333 & $85 \%$ & 4 \\
\hline Pebassian & 172 & 167 & $97 \%$ & 4 \\
\hline Mambulilling & 211 & 177 & $84 \%$ & 4 \\
\hline Bombong Lambe & 265 & 182 & $69 \%$ & 3 \\
\hline Bubun batu & 242 & 234 & $97 \%$ & 4 \\
\hline & 4248 & 3492 & & \\
\hline
\end{tabular}


4. Perangkingan dan Mapping berdasarkan Kondisi Sanitasi

Metode perangkingan berdasarkan kondisi sanitasi (tingkat kepemilikan jamban), dengan pendekatan sebagai berikut:

a. Nilai 1 diberikan apabila prosentase penduduk terlayani jamban sehat rendah yaitu $<25 \%$.

b. Nilai 2 diberikan apabila prosentase penduduk terlayani jamban sehat sedang yaitu $25-50 \%$.

c. Nilai 3 diberikan apabila prosentase penduduk terlayani jamban sehat tinggi yaitu 51-75\%.

d. Nilai 4 diberikan apabila prosentase penduduk terlayani jamban sehat sangat tinggi yaitu $>75 \%$

Untuk perangkingan daerah perencanaan berdasarkan tingkat kepemilikan jamban dapat dilihat pada tabel berikut:

Tabel 11.Perangkingan Daerah Perencanaan Berdasarkan Tingkat Kepemilikan Jamban

\begin{tabular}{|l|c|c|c|c|}
\hline Desa/Kelurahan & $\begin{array}{c}\text { Jml } \\
\text { Pddk } \\
\text { (jw) }\end{array}$ & $\begin{array}{c}\text { Jml Pddk } \\
\text { terlayani } \\
\text { jamban } \\
\text { sehat (jw) }\end{array}$ & $\begin{array}{c}\text { \% } \\
\text { Terlayani }\end{array}$ & SKOR \\
\hline Mamasa & 5.137 & 288 & $6 \%$ & 1 \\
\hline Osango & 3.635 & 204 & $6 \%$ & 1 \\
\hline Rambu saratu & 2.017 & 113 & $6 \%$ & 1 \\
\hline Lambanan & 3.337 & 187 & $6 \%$ & 1 \\
\hline $\begin{array}{l}\text { Lembangna } \\
\text { Salulo }\end{array}$ & 700 & 39 & $6 \%$ & 1 \\
\hline Taupe & 1.542 & 86 & $6 \%$ & 1 \\
\hline Buntu Buda & 3.041 & 170 & $6 \%$ & 1 \\
\hline Tondok Bakaru & 2.013 & 113 & $6 \%$ & 1 \\
\hline Pebassian & 565 & 32 & $6 \%$ & 1 \\
\hline Mambulilling & 808 & 45 & $6 \%$ & 1 \\
\hline $\begin{array}{l}\text { Bombong } \\
\text { Lambe }\end{array}$ & 1.054 & 59 & $6 \%$ & 1 \\
\hline Bubun batu & 871 & 49 & $6 \%$ & 1 \\
\hline
\end{tabular}

5. Perangkingan dan Mapping berdasarkan Tingkat Kemauan Menerima Teknologi Air Limbah

Metode perangkingan berdasarkan tingkat kemauan masyarakat menerima teknologi air limbah, dengan pendekatan sebagai berikut:

a. Nilai 1 diberikan apabila tingkat menauan masyarakat dan dukungan pemerintah daerah tidak ada. b. Nilai 2 diberikan apabila tingkat menauan masyarakat dan dukungan pemerintah daerah rendah.

c. Nilai 3 diberikan apabila tingkat menauan masyarakat dan dukungan pemerintah daerah sedang.

d. Nilai 4 diberikan apabila tingkat menauan masyarakat dan dukungan pemerintah daerah tinggi.

Untuk perangkingan daerah perencanaan berdasarkan tingkat kemauan masyarakat menerima teknologi air limbahdapat dilihat pada tabel berikut:

Tabel 12.Perangkingan Daerah Perencanaan Berdasarkan Tingkat Kemauan Masyarakat Menerima Teknologi Air Limbah

\begin{tabular}{|l|c|r|}
\hline \multicolumn{1}{|c|}{ Desa/Kelurahan } & Jml Pddk (jw) & \multicolumn{1}{c|}{ SKOR } \\
\hline Mamasa & 5.137 & 4 \\
\hline Osango & 3.635 & 3 \\
\hline Rambu saratu & 2.017 & 2 \\
\hline Lambanan & 3.337 & 2 \\
\hline Lembangna Salulo & 700 & 2 \\
\hline Taupe & 1.542 & 2 \\
\hline Buntu Buda & 3.041 & 2 \\
\hline Tondok Bakaru & 2.013 & 2 \\
\hline Pebassian & 565 & 2 \\
\hline Mambulilling & 808 & 2 \\
\hline Bombong Lambe & 1.054 & 2 \\
\hline Bubun batu & 871 & 2 \\
\hline & 24.720 & \\
\hline
\end{tabular}

6. Perangkingan dan Mapping berdasarkan Tingkat Ketersediaan Pelayanan PDAM

Metode perangkingan berdasarkan tingkat ketersediaan pelayanan PDAM, dengan pendekatan sebagai berikut:

a. Nilai 1 diberikan apabila prosentase rumah tangga yang terlayani PDAM rendah, yaitu berada pada range $<25 \%$.

b. Nilai 2 diberikan apabila prosentase rumah tangga yang terlayani PDAM sedang, yaitu berada pada range $25-50 \%$.

c. Nilai 3 diberikan apabila prosentase rumah tangga yang terlayani PDAM tinggi, yaitu berada pada range $50-75 \%$. 
d. Nilai 4 diberikan apabila prosentase rumah tangga yang terlayani PDAM sangat tinggi, yaitu berada pada range $>75 \%$.

Untuk perangkingan daerah perencanaan berdasarkan tingkat ketersediaan pelayanan PDAM dapat dilihat pada tabel berikut:

Tabel 13. Perangkingan Daerah Perencanaan Berdasarkan Tingkat Ketersediaan Pelayanan PDAM

\begin{tabular}{|l|r|r|r|r|}
\hline \multicolumn{1}{|c|}{ Desa/Kelurahan } & \multicolumn{1}{c|}{$\begin{array}{l}\text { JML } \\
\text { RT }\end{array}$} & \multicolumn{1}{c|}{$\begin{array}{c}\text { RT terlayani } \\
\text { PDAM }\end{array}$} & $\begin{array}{c}\text { Terlayani } \\
\text { SKOR }\end{array}$ \\
\hline Mamasa & 1173 & 43 & $4 \%$ & 1 \\
\hline Osango & 837 & NO & 0 & 1 \\
\hline Rambu saratu & 452 & NO & 0 & 1 \\
\hline Lambanan & 772 & NO & 0 & 1 \\
\hline Lembangna Salulo & 157 & NO & 0 & 1 \\
\hline Taupe & 345 & NO & 0 & 1 \\
\hline Buntu Buda & 681 & NO & 0 & 1 \\
\hline Tondok Bakaru & 451 & NO & 0 & 1 \\
\hline Pebassian & 127 & NO & 0 & 1 \\
\hline Mambulilling & 181 & NO & 0 & 1 \\
\hline Bombong Lambe & 236 & NO & 0 & 1 \\
\hline Bubun batu & 195 & NO & 0 & 1 \\
\hline & 5607 & & & \\
\hline
\end{tabular}

Skor masing-masing kriteria akan dikalikan bobot, kemudian seluruh hasil penilaian dijumlahkan. Jumlah penilaian tertinggi dikurangi jumlah penilaian terendah akan menjadi selisih interval. Selisih interval tersebut dibagi menjadi 3 klasifikasi yaitu prioritas jangka panjang, jangka menengah dan jangka pendek/ prioritas mendesak.

a. jangka panjang apabila hasil seluruh penilaian berada pada range 125,0-173,3.

b. jangka menengah apabila hasil seluruh penilaian berada pada range 173,4-221,6.

c. jangka pendek/prioritas mendesak apabila hasil seluruh penilaian berada pada range 221,7270,0

Dari hasil perhitungan diatas, dapat disimpulkan bahwa terdapat 1 desa/ kelurahan yang masuk dalam klasifikasi zona prioritas mendesak. Kelurahan Mamasa di Kecamatan Mamasa yang masuk dalam zona B skor 270, memiliki skor tertinggi diantara desa lainnya sehingga menjadi usulan prioritas lokasi pembangunan SPAL skala kawasan.

Berdasarkan rencana pengelolaan kawasan permukiman perkotaan maupun perdesaan di Kabupaten Mamasa tersebut, maka terdapat potensi air limbah domestik yang berasal dari perumahan formal maupun kegiatan pendukungnya, seperti usaha pengolahan hasil pertanian, perkebunanan, pariwisata, dan sentra ekonomi lainnya.

Pada pengembangan kawasan permukiman khusunya permukiman baru sebagai akibat adanya perkembangan infrastruktur diharapkan memiliki Rencana Induk Sistem Pengelolaan Air Limbah tersendiri yang terintegrasi dan berpedoman pada Rencana Induk Sistem Pengelolaan Air Limbah di Kabupaten Mamasa.

\section{Pengelolaan Air Limbah Desa/Kelurahan Mamasa}

Pengembangan prasarana pengelolaan air limbah di Kelurahan Mamasa saat ini belum berjalan secara optimal. Hal tersebut dapat diamati dari masih adanya masyarakat yang melakukan BAB sembarangan. Selain itujuga belum memiliki sarana pengelolaan limbah komunal seperti Instalasi Pengolahan Air Limbah (IPAL). Di sisi lain, sarana pengelolaan air limbah yang ada saat ini berupa MCK individual, MCK umum, Sarana Pembuangan Air Limbah (SPAL) juga belum sepenuhnya sesuai dengan standar teknis yang ada dan belum secara merata dimiliki dan dimanfaatkan oleh masyarakat sebagai sarana pengelolaan air limbah.Untuk mencapai tujuan dan target penanganan sistem pengelolaan air limbah, maka sistem pengelolaan dan pelayanan air limbah yang dapat diterapkan terdiri dari:

a. Sistem on site individual

b. Sistem on site komunal

c. Sistem off site kawasan

Teknologi pengolahan air limbah yang dapat digunakan sesuai dengan sistem pengelolaan dan pelayanan air limbah yang diterapkan tersebut diantaranya adalah:

a. MCK individual dilengkapi dengan Tangki Septik untuk sistem on site Individual

b. Tangki Septik Komunal untuk sistem on site komunal

c. IPAL kawasan untuk sistem off site kawasan Strategi pengembangan prsarana pengelolaan air limbah di Kecamatan Mamasa dilakukan 
berdasarkan arahan zona prioritas untuk masing masing distrik yang ada dan jangka waktu perencanaan, diantaranya :

a. Pada jangka pendek strategi sistem pengelolaan air limbah akan diarahkan untuk meningkatkan sistem on site individual dengan didukung oleh sistem on site komunal dan IPAL kawasan dalam rangka memperbaiki kondisi sanitasi pada daerah dengan kondisi sanitasi buruk dan meningkatkan akses terhadap kepemilikan sanitasi dasar yang layak,

b. Pada jangka menengah strategi sistem pengelolaan air limbah akan tetap diarahkan melakukan peningkatan sistem on site individual dengan didukung oleh penambahan IPAL kawasan dalam rangka pemerataan kepemilikan sanitasi dasar di Kabupaten Mamasa dan mencapai target pelayanan terhadap pengelolaan air limbah sebesar $100 \%$,

c. Pada jangka panjang perencanaan sistem pengelolaan air limbah akan diarahkan pada peningkatan persentase pengelolaan air limbah melalui sistem off site kawasan melalui peningkatan jumlah IPAL kawasan pada zona - zona prioritas,

\section{SIMPULAN}

1. Pengelolaan limbah di Kecamatan Mamasa ditentukan oleh hasil skoring melaluiPenentuan Zona Perencanaan dan Penentuan Zona Prioritas

2. Hasil penilaian rata-rata skor Penentuan Zona Perencanaan, Desa/ kelurahan yang memerlukan SPAL terpusat skala kawasan adalah Desa/Kelurahan Mamasa dan Osango

3. Hasil perhitungan skoring Penentuan Wilayah Prioritas Kelurahan Mamasa masuk dalam zona B skor 270, dengan skor tertinggi sehingga menjadi usulan prioritas lokasi pembangunan SPAL skala kawasan.

\section{DAFTAR PUSTAKA}

Asmadi, S. dan Suharno, S., 2012,Dasar-dasar teknologi pengolahan air limbah, Gosyen Publishing, Yogyakarta.

Ehlers, V. M., and Steel, E. W., 1950, Municipal and Rural Sanitation (Ed. 4). McGraw-Hill Book Company, Inc. New York.
Damanhuri, E., and Padmi, T., 2010, Pengelolaan sampah, Diktat Kuliah TL, 3104: 5-10.

Darsono, V., 2007, Pengolahan limbah cair tahu secara anaerob dan aerob, Jurnal Teknologi Industri, 11(1): 9-20.

Kaswinarni, F.,2007, Kajian Teknis Pengolahan Limbah Padat dan Cair Industri Tahu Studi Kasus Industri Tahu Tandang Semarang, Sederhana Kendal dan Gagak Sipat Boyolali, Doctoral dissertation, Program Pasca Sarjana Universitas Diponegoro.

Manurung, R.,2004, Proses Anaerobik Sebagai Alternatif Untuk Mengolah Limbah Sawit, Program Studi Teknik Kimia. e-USU Repository. Universitas Sumatera Utara.

Muhamad, D. S.,2015, SIG untuk memetakan daerah banjir dengan metode skoring dan pembobotan (studi kasus kabupaten Jepara), Skripsi, Fakultas Ilmu Komputer. Universitas Dian Nuswantoro Semarang.

Notoatmodjo S. 2007. Pengantar Pendidikan dan Ilmu Kesehatan Masyarakat, Andi Offset, Yogyakarta.

Nurhidayat, A., dan Hermana, J.,2009, Strategi Pengelolaan Air Limbah Domestik Dengan Sistem Sanitasi Skala Lingkungan Berbasis Masyarakat Di Kota Batu Jawa Timur. Prosiding Seminar Nasional Manajemen Teknologi X Program Studi MMT-ITS, Surabaya.

Nurmayanti, 2002, Kontribusi Limbah domestik terhadap Kualitas Air Kaligarang Semarang. Program Pasca Sarjana Universitas Gajahmada. Yogyakarta.

Rhomaidi, 2008, Pengelolaan Sanitasi secara terpadu Sungai Widuri : Studi Kasus Kampung Nitiprayan Yogyakarta, Skripsi, Teknik Lingkungan Fakultas Teknik Sipil dan Perencanaan Universitas Islam Indonesia, Yogyakarta.

Siregar, S.A., 2005, Instalasi Pengolahan Air Limbah, Kanisius, Yogyakarta. 
Wulandari, P. R., 2014, Perencanaan Pengolahan Air Limbah Sistem Terpusat (Studi Kasus di Perumahan PT. Pertamina Unit Pelayanan III Plaju-Sumatera Selatan), Journal of Civil and Environmental Engineering, 2(3):499509 . 